\title{
European Design Law: Considerations Relating to Protection of Spare Parts for Restoring a Complex Product's Original Appearance
}

\author{
Dana Beldiman • Constantin Blanke-Roeser
}

(C) Max Planck Institute for Innovation and Competition, Munich 2015

Policymakers have long struggled with the question whether design protection for spare parts of a complex product extends to the spare part aftermarket, or whether that market should remain open to competition. The stakeholders' equally weighty arguments are, on the one hand, the property interest in an earned IP right in the design of the part, and on the other, enhanced competition, likely reflected in lower prices. In EU law, this debate turns on adoption by Directive 98/71/EC on the legal protection of designs (Directive), ${ }^{1}$ of the so-called "repair clause", a provision exempting certain spare parts from design protection.

\section{Legal Background}

Directive 98/71/EC and Council Regulation (EC) No. 6/2002 on Community designs (CDR), ${ }^{2}$ operate in parallel; the former is meant to harmonize national legislation, ${ }^{3}$ whereas the latter provides a single EU-wide design right. ${ }^{4}$ National

\footnotetext{
1 Directive 98/71/EC of the European Parliament and of the Council of 13 October 1998 on the legal protection of designs.

${ }^{2}$ Council Regulation (EC) No. 6/2002 of 12 December 2001 on Community designs.

3 Wandtke A and Ohst C, 2005 GRUR Int. p. 91; Pentheroudakis, 2005 GRUR Int. p. 668 et seq.

4 More in-depth treatment in Kur, 2002 GRUR p. 661 et seq.
}

D. Beldiman $(\bowtie)$

Professor, Dr.; Bucerius Law School, Academic Director of the Center for Transnational IP, Media and Technology Law and Policy

Bucerius Law School, Hamburg, Germany

e-mail: dbeldiman@cbmlaw.com

C. Blanke-Roeser

Ph.D. student with Professor Dr. Axel Metzger, LL.M., at the Humboldt University of Berlin, as well as Research Assistant at the IP Center

Berlin, Germany 
design regulations in EU Member States, such the Designgesetz (DesignG) in Germany, are subject to the Directive. At the outset, the Directive and the CDR started from a common draft, both meant to "Europeanize" design law throughout the EU. ${ }^{5}$ Accordingly, these two legal instruments treat design protection largely in the same manner. ${ }^{6}$ Both laws protect complex products "composed of multiple components which can be replaced permitting disassembly and re-assembly of the product." ${ }^{7}$ Both laws further exclude from protection appearance features that must be reproduced exactly in order to allow a part to be incorporated into or connected with a complex product, aka "must fit" parts, ${ }^{8}$ because they are dictated by functional considerations. ${ }^{9}$ When it comes to replacement parts for complex products, however, the two laws part company. ${ }^{10}$ They differ in their treatment of those parts of a complex product whose shape is dictated by the product's overall appearance, which are visible, and therefore play a part in the appearance of the product also known as "must-match" parts. ${ }^{11}$ The most common such parts are automotive collision parts, such as fenders, lights, etc. ${ }^{12}$ Article 110.1 of the CDR excludes from protection must-match parts, which would otherwise be subject to design protection, to the extent they are used to restore the original appearance of the product, aka the "repair clause".

The Directive, however, has not adopted the repair clause. After lengthy negotiations ${ }^{13}$ the choice between adopting and not adopting the repair clause as a harmonized model ended up being a choice for non-harmonization. ${ }^{14}$ Article 14 of the Directive allows Member States to retain the legal status quo on spare parts design protection, until the Commission proposes amendments to the Directive, also referred to as the "freeze-plus" provision. Changes to national legislation are permissible only for the purpose of liberalizing the market for spare parts. A new proposal by the Commission made in 2004, was never acted upon and finally withdrawn in 2014.

\footnotetext{
5 See Kur A, 2002 GRUR p. 661; Beier, 1994 GRUR Int. p. 716 et seq.; Riehle G, 1993 GRUR Int. pp. 49, 50.

6 See Kur A, 2002 GRUR p. 661; Riehle G, 1993 GRUR Int. pp. 49, 50.

7 CDR Art. 3(c) and Dir 2(c).

${ }^{8}$ CDR Art. 8.2 and Directive 7(2).

9 But they might be subject to patent law (Pentheroudakis, 2002 GRUR Int. pp. 668, 671).

${ }^{10}$ Kur A, 1998 GRUR Int. pp. 977, 981 et seq.

11 Rehmann T, Designrecht, pp. 25 et seq.; Wandtke A and Ohst C, 2005 GRUR Int. pp. 91, 97.

12 Büscher W, Dittmer S and Schiwy-Steinberg P, GGV, Art. 4 No. 16; Bulling A, Langöhrig A and Hellwig T, Geschmacksmuster p. 46; Eichmann H, 1997 GRUR Int. pp. 595, 600. See also Beier F-K, 1994 GRUR Int. pp. 716, 718.

13 Pentheroudakis, 2002 GRUR Int. pp. 668, 684; Kur A, 2002 GRUR pp. 661, 669; Kur A, 1998 GRUR Int. pp. 977, 977; see Recital 19 Directive.

14 Cf. Berns E, Marktmissbrauch, p. 224; Kur A, 1999 IIC p. 620; Kur A, 1998 GRUR Int. p. 977 et seq.
} 


\section{Lack of Harmonization}

Given lack of harmonization on the repair clause, Member States have chosen differing paths. Germany's new design law, enacted in 2014, for instance, has opted against adoption of the clause and maintained its prior design law. Whether or not to adopt the repair clause ${ }^{15}$ was hotly debated in Germany, and the decision not to adopt was associated with the automotive manufacturers' agreement to refrain from asserting their IP rights, so as to avoid restricting competition in the retail market. ${ }^{16}$ Some countries adopted the clause, but many others declined. ${ }^{17}$ So far, the CJEU has decided only one case relating to the repair clause, ${ }^{18}$ eschewing an in-depth discussion of its scope and impact. Indeed, the decision on the repair clause may be a matter best left to the legislator. In 2014, the Commission manifested its intention to resume the issue by commissioning studies on the economic ${ }^{19}$ and the legal effects $^{20}$ of industrial design.

This debate is not limited to Europe. In the US, proposals for legislation have been made to successive Congressional sessions since $2008 .^{21}$ The interests are similarly aligned and the arguments in favor and against adoption of a repair clause equally similar. One notable difference is the fact that the provisions of the proposed bills have changed in the course of the years. From a broad, across-the-board exclusion of replacement parts applicable to all industries, the clause was narrowed to provide a limited period of protection of 30 months and to only specified motor vehicle parts (collision parts). ${ }^{22}$

\section{The Competitive Environment}

The reason why the decision in this matter is so difficult lies in the peculiarity of the parts and their market, as best illustrated by the automotive industry, the industry primarily affected by the repair clause. Typically, an individual part of a complex

\footnotetext{
15 See "Beschlussempfehlung und Bericht des Rechtsausschusses", BT doc. 15/2191, p. 8; and introduction Wandtke A and Ohst C, 2005 GRUR Int. pp. 91, 98.

16 See BT doc. 15/1075.

17 Tribunale Ordinario di Torino (Court of Turin), Company Law Division (Court of Community Trademarks as per. EC Re. 207/09, Art. 95) - Ford Motor Company/Wheeltrims s.r.l., Judgement, Docket No. 16531 RG 2013. The CJEU decided on the 6 October 2015 - C-500/14.

18 In Ford $v$. Wheeltrims, Case C-500/14 the Italian court limited its holding to the fact that Art. 14 of the Directive and Art. 110 of the CDR do not permit the unauthorized use of a registered trademark for the purpose of restoring the original appearance a complex product, in this case, use of the mark Ford by a manufacturer of wheel rims.

19 The Economic Review on Industrial Designs in Europe, accessible at: http://ec.europa.eu/growth/ industry/intellectual-property/industrial-design/protection/index_en.htm.

20 The Legal Review on Industrial Designs in Europe. Contractor: time.lex CVBA. Time frame: 12 months, beginning: 24 November 2014.

21 U.S. Bill H.R. 1057 and Sec. 560 to amend 35 USC Sec. 271 (2015).

22 The bill provides an exception from design patent infringement for: (a) using and selling for 30 months after the product ahs first been offered for sale, and (b) making, offering for sale and importing.
} 
product is developed in the context of producing and distributing the product on a competitive open market (primary market). Distribution of the spare part takes place in the aftermarket, in which the original manufacturer holds considerable market power, and competitors face hurdles to market entry. This is due, in part, to the nature of the parts at issue. Because the parts serve for recreating the complex product's (often an automobile's) original appearance, they must perfectly match the original specifications, in terms of appearance, size, shape, connectivity, etc., absent which they are useless for their intended purpose. As a competitor typically lacks access to the original manufacturer's production know-how, it must invest in $\mathrm{R} \& \mathrm{D}$ to reverse engineer the spare parts to make them fit within the original manufacturer's tolerances. Further investment is required in production lines and distribution networks, an investment that the original manufacturer has already made and likely amortized by sales in the primary market. ${ }^{23}$ As a result, purchasers' choice of spare parts may be limited, both due to lack of competition, and as a result of a "lock-in" into the original manufacturer's product as a result of warranty/ service contracts, of brand loyalty, etc.

Given the already existing market power, proponents of market liberalization argue in favor of a repair clause on the ground that IP protection is not apposite. The reasons include the fact that the secondary market is not an innovation market, that the investment into innovation has already been amortized through sales in the primary market and that the design premium due for the innovative design has been realized in the primary market. Accordingly, there is no need for the incentive function provided by IP protection. ${ }^{24}$ Liberalization of the market would result in enhanced competition and lower prices. ${ }^{25}$

Opponents of the repair clause argue that IP law is indifferent to the differentiation between primary and secondary markets. The very nature of an IP right is to provide exclusivity in the market, i.e. to place the rightholder in a competitively superior position. A repair clause would prevent rightholders from exploiting the exclusivity inherent in their IP right in the secondary market and thus interfere with their constitutionally guaranteed property rights. ${ }^{26} \mathrm{~A}$ law in the nature of a repair clause would benefit others at the expense of the impacted industries. Furthermore, so the argument, enactment of a repair clause for spare parts serving to restore the appearance of the product, may set a dangerous precedent for similar decisions relating to utility patents. ${ }^{27}$

In short, the repair clause presents a most complex question situated at the intersection of IP law and competition law. Whether viewed through a competition law or an IP law lens, the obvious policy choices of adoption or non-adoption of the

\footnotetext{
23 See Klein B, "Market Power in Aftermarkets", 17 Managerial \& Decision Economics p. 143 et seq. (1996). See also Drexl J, Hilty RM and Kur A, 2005 GRUR Int. p. 449 et seq.

24 Id.

25 Cf. Riehle G, 1993 GRUR Int. pp. 49, 55.

26 See for instance, Art. 14 of the German Constitution (Grundgesetz); Art. 345 of the TFEU; or the 5th and 14th Amendments of the US Constitution.

27 Straus J., 2005 GRUR Int. p. 959 et seq.; AIPLA, Draft Resolution on the 2105 PARTS Bill, accessible at: https://www.google.com/?gws_rd=ssl\#q=aipla+industrial+designs+draft+resolution+2015.
} 
repair clause would lead to an unbalanced result. Given the diametrically opposed views of the stakeholders, such binary, all-or-nothing approach would be staunchly opposed by one or the other side. Better balance and acceptance by stakeholders would be achieved by a more nuanced solution. To explore the scope of possible flexibilities of the repair clause, in October 2015, the Bucerius Law School's IP Center held an expert roundtable discussion with representatives of all major stakeholders. A publication containing a more detailed examination of the considerations addressed is forthcoming in 2016. 